LINGUA, Vol. 16, No. 1, Maret 2019

p ISSN: 1979 9411; e ISSN: 2442 238X

Http://lingua.pusatbahasa.or.id; Email:presslingua@gmail.com

Center of Language and Cultural Studies, Surakarta, Indonesia

Fitri, Mahyuni \& Sudirman. 2019. Skemata Wacana Humor Stand Up Comedy Indonesia.

Lingua (2019), 16(1): 65 76. DOI: 10.30957/lingua.v16i1.575.

\title{
SKEMATA WACANA HUMOR STAND UP COMEDY INDONESIA
}

\author{
Fitri, Mahyuni \& Sudirman \\ Magister Pendidikan Bahasa Indonesia Universitas Mataram \\ Jalan Majapahit No. 62 Kota Mataram Nusa Tenggara Barat \\ Email: fitriviinia95@gmail.com
}

\begin{abstract}
This qualitative research design was conducted to describe the schema, cohesion, coherence, and context contained in the stand up comedy performed by famous comics (performer of stand up comedy) in Indonesia. The data were in the form the text of stand up comedy performed by Raditya Dika, Ernest Prakarsa, and Pandji Pragiwaksono. The source of the data was videoaudio stand up comedy on Youtube http://www.youtube.com. The data gathered and analyzed grounded in theory of schematic, cohesion, coherence, and humorous discourse. The results show that the schemata appears in the set up section and each schema appears based on the experience of comics. The schema appears varously including dating, children, family, education, personal experience, social and so forth. The cohesion found in the stand up comedy performed by the comics is only a few and without coherence in it. The context rising also depends on the min theme of stand up comedy.
\end{abstract}

Keyword: schematic, discourse, humorous, comics, Indonesia.

DOI: 10.30957/lingua.v16i1.575.

\section{PENDAHULUAN}

Stand up comedy atau komedi tunggal adalah jenis lawakan baru dari Amerika dan Inggris. Lawakan ini dilakukan satu orang yang disebut komika. Komika bercerita mengenai suatu topik, kemudian dikembangkan menjadi materi komedi. Lawakan ini biasanya dilakukan dengan cara berdiri di tengah-tengah panggung dan disaksikan secara langsung olehkhalayak penonton. Biasanya, komika membawakan materi berupa fenomena sosial dalam kehidupan sehari-hari. Keberadaan stand up comedy sangat mengharapkan kehadiran penonton, karena keberadaan khalayak penonton, sangat penting dalam stand up comedy. karena Di samping itu, komika memerlukan penonton untuk merespon lelucon yang dibawakan. Komika dikatakan berhasil menampilkan stand up comedy, apabila para penonton memiliki antusiasme humoris atau dapat tertawa. Kehadiran penonton sangat diperlukan komika untuk melakukan stand up.

Papana (2016) menyatakan bahwa perbedaan sosial budaya antara Amerika, Inggris dan Indonesia membuat banyak teori dan rumus dari stand up comedy yang berlaku di luar negeri tidak bisa sepenuhnya diterapkan di Indonesia. Hal ini dikarenakan terdapat norma-norma yang berlaku di masyarakat dan hal itu membatasi komika untuk membicarakan sesuatu yang berada diluar dari norma di Indonesia. Oleh 
LINGUA, Vol. 16, No. 1, Maret 2019

p ISSN: 1979 9411; e ISSN: 2442 238X

Http://lingua.pusatbahasa.or.id; Email: presslingua@gmail.com

Center of Language and Cultural Studies, Surakarta, Indonesia

Fitri, Mahyuni \& Sudirman. 2019. Skemata Wacana Humor Stand Up Comedy Indonesia.

Lingua (2019), 16(1): 65 76. DOI: 10.30957/lingua.v16i1.575.

karena itu, para komika di Indonesia lebih berhati-hati dalam memilih dan membawakan materi stand up comedy-nya di hadapan masyarakat umum.

Di Indonesia terdapat beberapa nama tokoh stand up comedy yang dianggap paling berpengaruh dalam perkembangan stand up comedy, yaitu: Raditya Dika, Ernest Prakasa, dan Panji Pragiwaksono. Ketiga komika tersebut adalah komika yang sudah terkenal di seluruh Indonesia, bahkan sampai luar negeri. Mereka juga mendirikan sebuah komunitas stand up comedy yang diberi nama Stand Up Comedy Indonesia atau singkatmya Stand Up Indo.

Setiap tahun mereka membuat konser atau pertunjukkan stand up comedy tunggal, misalnya Raditya Dika membuat pertunjukan stand up comedy setiap akhir tahun disebuah kampus atau universitas ternama, kemudian Panji membuat pertunjukan stand up comedy yang diadakan sampai ke luar negeri, tidak hanya Asia tetapi, tetapi sampai ke benua Eropa. Selanjutnya, Ernest membuat pertunjukan stand up comedy di salah satu gedung mewah di Jakatra dan disaksikan ribuan orang. Ketiga komika tersebut memiliki gayabahasa yang khasdengan topik-topik pembicaraan yang berbeda. Materi pembicaraan bergantung pada sudut mana seorang komika melihat suatu permasalahan atau kegelisaan sosial untuk ditampilkan dalam materi stand up. Misalnya, Raditya Dika memilih topik stand up seputar kehidupannya sehari-hari hingga masalah percintaan, karena melihat dari sudut pandang seorang Radit yang saat itu baru kembali berpacaran setelah bertahun-tahun jomblo. Kemudian materi stand up dari sudut pandang seorang Panji membicarakan topik yang lebih ke arah motivasi, misalnya pendidikan, mengasuh anaknya, hingga masalah demokrasi. Sedangkan itu, Ernest membicarakan materi stand up mengenai topik-topik seputar anak dan keluarganya.

Tahun 2017 sampai awal tahun 2018 masyarakat Indonesia dihebohkan dengan kasus beberapa komika yang dianggap menghina agama dan memasukan unsur SARA (Suku, Agama, dan Ras) dalam materi stand up comedy yang dibawakan. Beberapa komika, seperti Ge Pamungkas, Joshua Suherman, dan Uus harus beberurusan dengan pihak kepolisian. Ge Pamungkas dilaporkan ke polisi setelah melakukan open mic atau stand up comedy yang dilakukan pada November 2017. Pada saat tampil Ge membuat masyarakat resah karena materi yang dibawa dianggap menghina agama dan membawa unsur SARA dalam materi tentang banjir yang menimpa Jakarta, kemudian Joshua yang juga dilaporkan atas tuduhan yang diduga memuat unsur sara dalam bagian punchline (bagian klimaks terlucu dari komedi yang disampaikan) tentang mayoritas minoritas agama di Indonesia. Hal serupa juga dialami Uusyang harus berhadapan dengan pihak kepolisian, sehingga ia dipecat dari beberapa acara TV terkait dengan tweet-nya yang dianggap sebagai penistaan terhadap tokoh agama.

Pandji Pragiwaksomo juga pernah menyinggung pihak media cetak Post Kota ketika menyampaikan stand up mengenai seorang ustad yang sedang berceramah dan dikaitkan dengan Post Kota sebagai media yang menampilkan berita kriminal. Namun, berbeda dengan kasus Ge dan Joshua, kasus yang dihadapi oleh Pandji yaitu golongan masyarakat yang membela ulama dan media Post Kota yang tersinggung dengan materi stand up-nya, karena mediaPost Kota disebutkan dalam materi stand up-nya. 
LINGUA, Vol. 16, No. 1, Maret 2019

p ISSN: 1979 9411; e ISSN: 2442 238X

Http://lingua.pusatbahasa.or.id; Email: presslingua@gmail.com

Center of Language and Cultural Studies, Surakarta, Indonesia

Fitri, Mahyuni \& Sudirman. 2019. Skemata Wacana Humor Stand Up Comedy Indonesia.

Lingua (2019), 16(1): 65 76. DOI: 10.30957/lingua.v16i1.575.

Penyelesaian kasus ini dilakukan secara musyawarah dan Pandji meminta maaf hingga membuat sebuah video tentang klarifikasi sekaligus permintan maaf kepada Post Kota. Pandji menjelaskan bahwa yang disampaikan itu tidak bermaksud menyinggung pihak manapun. Jadi dalam komedi kesalahpahaman itu sering terjadi karena setiap orang punya persepsi atau skemata yang berbeda ketika mendengar suatu lelucon yang diutarakan komika ketika tampil dan materinya dianggap sensitif untuk didengar masyarakat.

Terkadang sebuah stand up bisa terdengar lucu karena skemata yang disampaikan oleh komika tersebut sesuai dengan skemata yang dimiliki oleh penonton. Namun, terkadang ada materi stand up comedy yang dianggap tidak lucu, sehingga tidak memberikan efek humoris terhadap penonton. Faktor yang menyebabkan materi stand up dianggap tidak humoris, yakni: pertama penonton tidak mempunyai skemata yang sesuai sehingga tidak dapat memahami apa yang disampaikan komika. Kedua, penonton memiliki skemata yang sesuai saat itu, tetapi petunjuk skemata yang disampaikan oleh komika tidak cukup kuat. Ketiga, penonton tidak mendapatkan pemahaman materi yang relevan dengan konsep pemikiran yang ditawarkan oleh komika. Kasus komika yang dianggap menghina agama, banyak sekali orang yang bersuara dan mereka memberikan opini bahwa yang dikatakan oleh para komika tersebut bukanlah suatu bentuk penodaan agama, melainkan hanya menyuarakan kegelisahan yang orang lain yang tidak peka terhadap fenomena sosial. Misalnya, Joshua membicarakan tentang mayoritas dan minoritas agama, banyak yang beropini bahwa hal itu hanya sekadar menyuarakan pendapatnya sebagai orang yang berada dalam posisi minoritas.

Berdasarkan kasus-kasus komika tersebut dapat dilihat bahwa ternyata peran skemata diperlukan untuk memahami maksud materi pembicara dari apa yang disampaikan oleh setiap komika. Selain skemata, terdapat pula konteks wacana, kohesi, dan koherensi untuk dapat melihat dan memahami isi dari stand up comedy.

Berdasarkan kasus-kasus kesalahpahaman dalam dunia stand up, khususnya di Indonesia, penelitian ini berfokus kepada materi yang disampaikan oleh para komika pada setiap pertunjukan tunggal, kemudian menjadikan materi yang dibawakan saat itu, sebagai objek penelitian untuk mencermati skemata, konteks wacana, kohesi dan koherensi apa saja yang terkadung dalam materi tersebut. Penelitian ini diharapkan dapat mengungkapkan dan mendeskripsikan skemata, konteks wacana, kohesi dan koherensi yang terdapat dalam isi stand up comedy tersebut. Tujuan penelitian, yakni para penikmat stand up comedy dapat memahami pesan yang ingin disampaikan komika dalam pertunjukan tunggalnya dan menghindari terjadinya kesalahpahaman.

\section{KAJIAN TEORI}

Wacana adalah rentetan kalimat yang berkaitan sehingga terbentuk makna yang serasi di antara kalimat-kalimat itu (Alwi, dkk., 2010:41). Hawtal (dalam Badara 2014:17) berpandangan bahwa wacana adalah komunikasi kebahasaan yang terlibat sebagai sebuah pertukaran di antara pembicara dan pendengar, sebagai sebuah aktivitas personal dimana bentuknya ditentukan oleh tujuan sosialnya. Sedangkan itu, Schiffrin 
LINGUA, Vol. 16, No. 1, Maret 2019

p ISSN: 1979 9411; e ISSN: 2442 238X

Http://lingua.pusatbahasa.or.id; Email: presslingua@gmail.com

Center of Language and Cultural Studies, Surakarta, Indonesia

Fitri, Mahyuni \& Sudirman. 2019. Skemata Wacana Humor Stand Up Comedy Indonesia.

Lingua (2019), 16(1): 65 76. DOI: 10.30957/lingua.v16i1.575.

(2007:582) menyatakan wacana digunakan untuk komunikasi: orang menggunakan tuturan untuk menyampaikan informasi dan untuk membimbing satu sama lain menuju interpretasi makna dan maksud/tujuan. Jadi dapat disimpulkan bahwa wacana merupakan suatu bentuk kebahasaan yang bertujuan untuk menyampaikan pikiran.

Di Indonesia salah satu wacana yang sedang populer adalah wacana humor, wacana humor seperti wacana pada umumnya ada yang berbentuk tulis ada pula yang lisan. Wacana humor adalah suatu jenis wacana yang berisikan humor atau cerita lucu yang dikemas dengan baik dan dapat berbentuk lisan maupun tulis. Salah satu contoh wacana humor lisan adalah stand up comedy.

Setiap wacana pasti memiliki skemata, skemata merupakan representasi pengetahuan tentang dunia yang digunakan sebagai sarana untuk menerjemahkan dan memahami sesuatu yang telah dibaca atau didengar. Skema merupakan struktur data yang mewakili konsep umum yang tersimpan dalam ingatan manusia.

Alwi, dkk(2010:458) Skemata mewakili pengetahuan kita tentang semua konsep yang berkaitan dengan objek, situasi, peristiwa dan urutan peristiwa, serta tindakan dan urutan tindakan. Kemudian, Black ( 2016:78-79) menyatakan skemata adalah benarbenar ada didasarkan pada kecepatan kita dalam mengolah bahasa dan gaya-gaya tidak ekplisit yang biasanya kita gunakan.

Skemata adalah pengetahuan umum mengenai suatu peristiwa atau situasi. Skemata dibagi menjadi dua yaitu skemata kognitif dan skemata dalam membaca. Skemata kognitif adalah suatu representasi bentuk dari ide, persepsi, dan aksi yang diasosiasikan dan merupakan kemampuan dasar dalam pembangunan pikiran. Skemata ini akan selalu berkembang seiring dengan banyaknya pengalaman (Piaget, 2001). Sedangkan skemata dalam membaca adalah suatu proses mendapatkan pengetahuan awal dari kegiatan membaca itu, kemudian membandingkan pengetahuan awal tersebut dengan pengetahuan baru. Jadi, skemata adalah kerangka berpikir yang telah terbentuk untuk mewakilkan ide, gagasan dalam diri seseorang yang telah memiliki pengetahuan awal dan pengalaman di masa lalu kemudian membandingkan dengan pengetahuan baru yang baru didapatkannya.

Selain skemata, dalam sebuah wacana yang berbentuk tulis maupun lisan pasti juga terdapat kohesi dan koherensi. Kohesi dan koherensi adalah dua unsur yang menyebabkan sekelompok kalimat membentuk kesatuan makna. Kohesi merujuk pada keterkaitan antarproposisi yang secara eksplisit diungkapkan oleh kalimat-kalimat yang digunakan. Koherensi juga mengkaitkan dua proposisi atau lebih, tetapi keterkaitan di antara proposisi-proposisi tersebut tidak secara eksplisit dinyatakan dalam kalimatkalimat yang dipakai (Alwi, dkk., 2010:41). Sedangkan koherensi menurut Yule (2014:144) apa yang ada dalam benak pemakai bahasa sebagai besar adalah suatu koherensi, yaitu apa yang dikatakan atau dituliskan mengandung arti sesuai dengan pengalaman normal mereka. Jadi, koherensi adalah suatu unsur yang terdiri dari wacana yang memiliki makna yang tidak langsung dinyatakan.

Halliday dan Hassan (1985:5) menyatakan bahwa konteks wacana adalah teks yang menyertai teks lain. Dalam Alwi, dkk (2010:434) konteks wacana terdiri atas 
LINGUA, Vol. 16, No. 1, Maret 2019

p ISSN: 1979 9411; e ISSN: 2442 238X

Http://lingua.pusatbahasa.or.id; Email:presslingua@gmail.com

Center of Language and Cultural Studies, Surakarta, Indonesia

Fitri, Mahyuni \& Sudirman. 2019. Skemata Wacana Humor Stand Up Comedy Indonesia.

Lingua (2019), 16(1): 65 76. DOI: 10.30957/lingua.v16i1.575.

berbagai unsur seperti situasi, pembicara, pendengar, waktu, tempat, adegan, topik peristiwa, bentuk amanat, kode dan sarana.

Salah satu tempat manusia untuk menuangkan ide pikirannya adalah melalui tulisan atau perkataan mereka. Tulisan-tulisan atau perkataan yang terucap merupakan hal yang secara langsung menunjukan jati diri mereka, bagaimana mereka melihat suatu permasalahan, suatu peristiwa dalam hidup. Banyak orang yang membuat tulisan atau perkataan tentang hidup dari sudut pandang mereka namun dituang dalam tulisan yang berisifat humor atau lucu. Misalnya komik, cerpen, novel, atau mereka sajikan dalam Stand up.

Wikipedia (2018) mendeskripsikan lawakan tunggal atau komedi tunggal (bahasa Inggris: Stand Up comedy, harfiah "komedi berdiri"), adalah salah satu genre profesi melawak yang pelawaknya (kadang disebut komika, bahasa Inggris: comic) membawakan lawakannya di atas panggung seorang diri, biasanya di depan pemirsa langsung, dengan cara bermonolog mengenai sesuatu topik. Orang yang melakukan kegiatan ini disebut pelawak tunggal (bahasa Inggris: stand-up comedian), komik, atau komik berdiri (komik tunggal). Lawakan mereka biasanya direkam dan kemudian dijual menjadi melalui DVD, internet, atau televisi.

Stand up comedy di Indonesia dipopulerkan dan kembangkan sejak tahun 2000an pada saat itu baru stand up comedy hanya ditonton di cafe sampai akhirnya bisa berkembang menjadi seperti sekarang ini, saat ini stand up comedy tak hanya di tampilkan di cafe-cafe saja namun sudah mulai dikembangkan di televisi hingga banyak stasiun televisi Indonesia membuat perlombaan atau ajang pencarian bakat bagi setiap orang yang ingin menjadi komika terkenal. Contonya saja MetroTV yang membuat acara pencarian bakat dengan nama "Stand up comedy Indonesia (SUCI)" dan Indosiar membuat acara dengan nama "Stand up comedy Academic (SUCA)". Televisi sudah menjadi wadah baru bagi komika pemula untuk mengembangkan kemampuan dan bakat mereka dalam berstandup. Seiring dengan banyaknya ajang pencarin bakat standup semakin terkenal nama-nama komika yang sudah dulu terjun dalam dunia standupyaitu Raditya Dika, Ernest Prakasa dan Pandji Pragiwaksono.

Teknik dalam stand up paling dasar adalah set up dan punchline. Set up adalah bagian ini adalah bagian tidak lucu dan sebagai pengantar sebuah lelucon. Punchline adalah bagian lucu dari sebuah lelucon yang dibelokan dan orang seharunya tertawa pada bagian ini.

\section{METODE}

Metode penyediaan data yang digunakan dalam penelitian ini adalah metode simak. Metode ini digunakan untuk memperoleh data dengan melalui cara menyimak penggunaan bahasa. Metode ini tak hanya dapat digunakan untuk meneliti bahasa lisan namun dapat digunakan juga untuk penelitian bahasa tulis. Disebut metode simak karena dilakukan dengan menyimak penggunaan bahasa oleh komunikasi baik dalam lisan atau tulisan. Jadi yang dapat disimak adalah satuan bunyi, rentetan kata, klausa, 
LINGUA, Vol. 16, No. 1, Maret 2019

p ISSN: 1979 9411; e ISSN: 2442 238X

Http://lingua.pusatbahasa.or.id; Email: presslingua@gmail.com

Center of Language and Cultural Studies, Surakarta, Indonesia

Fitri, Mahyuni \& Sudirman. 2019. Skemata Wacana Humor Stand Up Comedy Indonesia.

Lingua (2019), 16(1): 65 76. DOI: 10.30957/lingua.v16i1.575.

kalimat, intonasi, tekanan, jeda, orang dan cara menggunakan bahasa serta maksud satuan bahasa tertentu digunakan (Sudaryono dalam Muhuhammad, 2012:36).

Mahsun (2017:92-93) menyatakan bahwa teknik sadap disebut sebagai teknik dasar dalam metode simak karena pada hakikatnya penyimakan diwijudkan dengan penyadapan. Dalam prktiknya selanjutnya teknik sadap ini diikuti dengan teknik lanjutan yang berupa teknik simak libat cakap, simak bebas libat cakap, catat dan teknik rekam. Teknik catat adalah teknik lanjutan yang dilakukan ketika menerapkan metode simak dengan teknik lanjutan di atas.

Penelitian ini mengambil stand up comedy yang dilakukan oleh beberapa komika ternama di Indonesia sebagai data yang digunakan sehingga teknik yang digunakan dalam pengambilan data tersebut adalah teknik rekam dan catat. Data yang digunakan berupa video-video stand up comedy yang dilakukan oleh Raditya Dika, Ernest Prakasa dan Pandji Pragiwaksono. Sumber data didapatkan dari http://www.youtube.com dari channel komika masing-masing. Kemudian, video tersebut diunduh, dicermati, dan ditranskripsikan, sehingga pada akhirnya dapat memerikan aspek skemata, kohesi, koherensi dan konteks wacana.

\section{HASIL DAN PEMBAHASAN}

Berdasarkan hasil analisis dan pembahasan penelitian mengenai skemata, kohesi, koherensi dan konteks yang ada didalam stand up comedy para komika terkenal di Indonesia. Penelitian ini menemukan beberapa komposisi skema materi stand up yang dianggap khas dan mengidentikkan pembicara itu sendiri. Di antaranya, komika seperti Raditya Dika, Pandji Pragiwaksono, dan Ernest Prakarsa memiliki skemata materi sebagai berikut.

\subsection{Skemata Materi Stand Up para Komika}

Terdapat beberapa komposisi atau susunan skemata para komika dalam melakukan stand up comedy. Adapun skemata tersebut sebagai berikut.

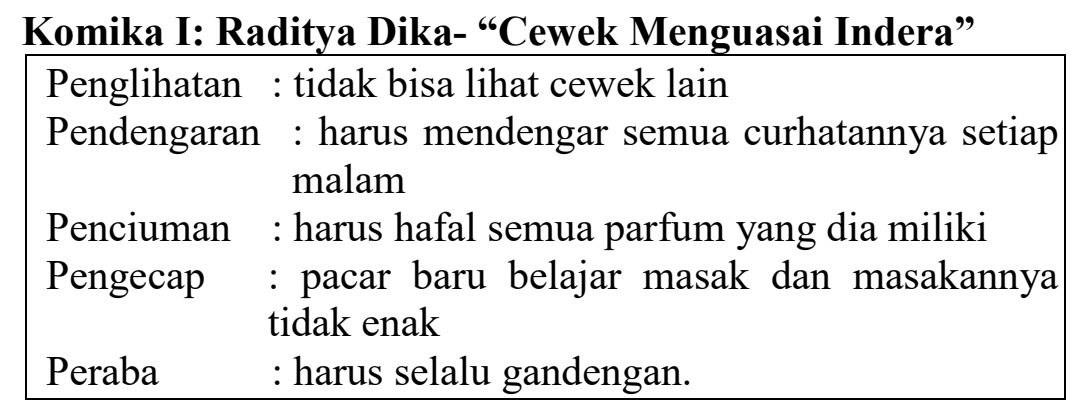

Data komika I memuat skematika pernyataan Raditya Dika yang menjelaskan bahwa orang yang jomblo harusnya merasa bahagia karena ketika seseorang mulai berpacaran maka seluruh inderanyaakan dikuasai oleh pacarnya. Dia menjelaskan seluruh indera yang manusia miliki mulai dari penglihatan, pendengaran, penciuman, pengecap dan peraba. 
LINGUA, Vol. 16, No. 1, Maret 2019

p ISSN: 1979 9411; e ISSN: 2442 238X

Http://lingua.pusatbahasa.or.id; Email: presslingua@gmail.com

Center of Language and Cultural Studies, Surakarta, Indonesia

Fitri, Mahyuni \& Sudirman. 2019. Skemata Wacana Humor Stand Up Comedy Indonesia.

Lingua (2019), 16(1): 65 76. DOI: 10.30957/lingua.v16i1.575.

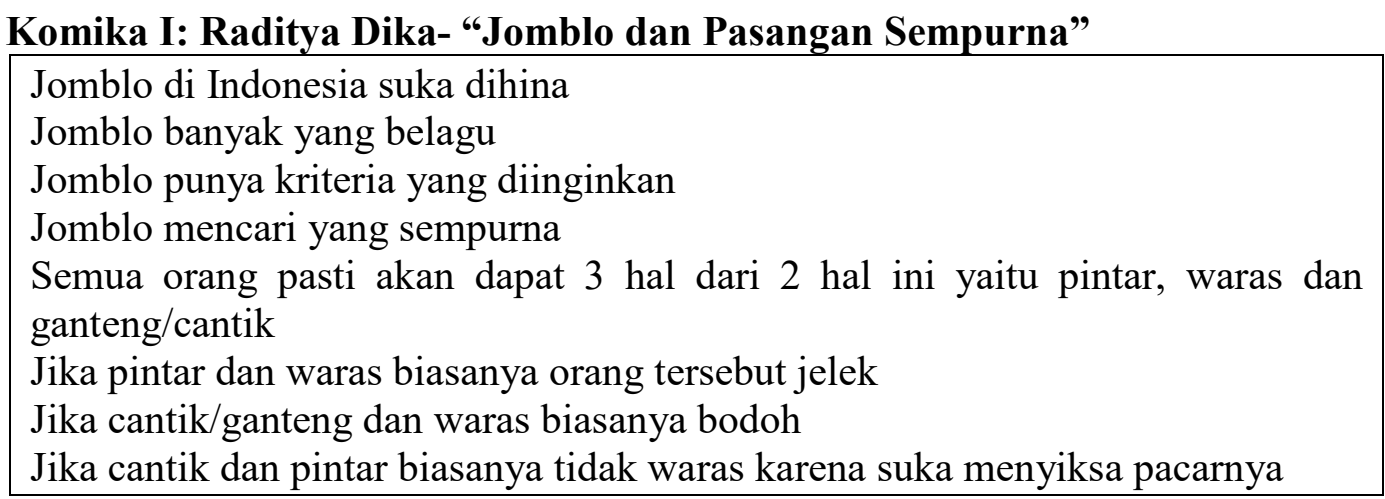

Data komika I berikutnya memuat pernyataan Raditya Dika yang menjelaskan kelakuan jomblo-jomblo di Indonesia. Mulai dari suka dihina, terlalu belagu, cari yang sempurna. Padahal yang dibutuhkan oleh jomblo-jomblo tersebut adalah mencari seseorang yang mau dijadikan kekasih. Selain itu, Radit menjelaskan bahwa tidak ada orang yang sempurna di dunia ini.

\section{Komika II: Pandji Pragiwaksono- "Pendidikan"}

Kepercayaan diri penting dan tidak bisa dibeli

Setiap orang punya bakat yang berbeda-beda

Pendidikan di Indonesia harus distandarisasi

Buat anak-anak minat dengan pelajaran bukan disuruh untuk menghafal

Guru harusnya menjadi idola

Data komika II memuat pernyataan Pandji yang menceritakan bagaimana dulu anaknya tidak percaya diri karena waktu TK nol besar belum bisa baca dan menulis. Pandji menjelaskan ke anaknya kalau setiap orang punya bakat masing-masing. Selain itu dia juga mengkritik pendidikan dan guru di Indonesia agar pendidikan yang diterapkan itu diminati bukan sekedar dihafalkan.

\section{Komika II: Pandji Pragiwaksono- "Satwa"}

Manusia bilang suka padahal menyiksa

Banyak hewan yang seharusnya bukan dipelihara

Kebun binatang secara harfiah itu adalah penjara binatang bukan bagian industri hiburan atau edukasi.

Sirkus hewan menyiksa hewannya untuk menghibur orang

Selanjutnya, komika II memuat pernyataan Pandji yang memberikan pandangan tentang hewan yang dipelihara manusia karena alasan suka, padahal hal itu sebenarnya menyiksa. Hewan dikandangkan, di masukan kebun binatang padahal secara harfiah itu mempenjarakan binatang. Sirkus hewan juga menjadi tempat untuk menyiksa binatang dengan memaksa mereka berhitung hanya untuk menyenangkan manusia. 
LINGUA, Vol. 16, No. 1, Maret 2019

p ISSN: 1979 9411; e ISSN: 2442 238X

Http://lingua.pusatbahasa.or.id; Email: presslingua@gmail.com

Center of Language and Cultural Studies, Surakarta, Indonesia

Fitri, Mahyuni \& Sudirman. 2019. Skemata Wacana Humor Stand Up Comedy Indonesia.

Lingua (2019), 16(1): 65 76. DOI: 10.30957/lingua.v16i1.575.

\section{Komika III: Ernest Prakarsa- "Sky Belajar Agama"}

Sky meniru perkataan orang tuanya

Sky menanyakan hal yang susah dijawab

Sky diajari tentang berdoa dan ketuhanan

Susah memahami bahwa ada lebih dari satu agama

Sky mengucapkan assalamualaikum ke Ayahnya

Materi stand up yang dibawakan oleh Ernest, ernest menceritakan tentang anaknya yang meniru perkataan ibunya dan mereka mencoba mengajari anaknya tentang konsep ketuhanan, namun untuk anak-anak masalah perbedaan agama itu belum dapat mereka pahami, hingga Sky anaknya Ernest mengucapkan salam assalamualaikum ketika mau pergi hingga Ernest bingung.

\section{Komika II: Ernest Prakarsa- "Horornya Toilet di Beijing"}

\section{Syuting film di Beijing}

Kendala komunikasi

Masalah sanitasi di stasiun kereta Beijing

Orang di Beijing ketika selesai menggunakan toilet orang tersebut "meninggalkan jejak"

Materi stand up yang ditampikan, Ernest menceritakan tentang pengalamannya syuting di kota Beijing. Ketika dia sedang berbelanja dia terkendala dengan bahasa, orang Cina mengira Ernest bisa berbahasa Mandarin namun ketika bicara Ernest menggunakan bahasa Inggris. Namun Ernest mendapat tatapan tajam dari orang Cina di sana. Kemudian Ernest terheran ketika melihat orang yang keluar dari toilet namun "meninggalkan jejak" atau kotorannya tidak disiram padahal toiletnya itu berada di stasiun kereta kota Beijing.

\subsection{Kohesi dan koherensi}

Penelitian ini menemuka penggunaan kohesi dan koeherensi pada teks standupyang dibawakan oleh para komika. Adapun deskripsinya sebagai berikut.

\section{a. Kohesi yang muncul dalam standup Raditya dika-Jomblo dan pasangan sempurna}

\section{Set up:}

"Yang gue kesel dari jomblo-jomblo ini bukannya kenapa-kenapa ya, tapi banyak yang belagu jadi kalau gue tanya " lo kenapa sih jomblo lama?"dia bilang "Gue mencari menunggu seseorang yang sempurna untuk diri gue".

Kalimat di atas menyatakan proposisi mengenai kenapa orang tersebut masih jomblo lalu dijawab dengan proposisi alasan yang orang tersebut. Keterkaitan ini dinyatakan dalam dua kalimat yag berkaitan. 


\section{Punchline:}

"temengue ini pernah sekali telat jemput si cewek ini di Grand Indonesia terus dia nelpon "Sayang sorry ya aku telat jemput kamu" "Oke, kamu cari aku di Grand Indonesia sekarang aku akan bersembunyi ..” (kohesi) demi Allah ni demi Allah ini kejadian nyata gua nggak mungkin ngarang cerita kayak gini “...dalam sepuluh menit kamu gak ketemu aku, aku akan pulang naik taksi"pinter, cantik, gila."

Kalimat di atas menyatakan proposisi mengenai seseorang yang meminta maaf karena telat menjemput pacarnya lalu dijawab oleh pacarnya untuk menjemputnya di Grand Indonesia. Keterkaitan ini dinyatakan dalam dua kalimat yag berkaitan.Jadi dari beberapa standup yang ditampilkan Raditya Dika hanya terdapat kohesi dan tidak semua standupnya yang terdapat kohesi.

\section{b. Kohesi muncul dalam stand up comedy Ernest Prakasa- "Sky belajar agama" Punchline:}

"Suatu hari lagi saat kita lagi liburan di Bandung, Sky bilang gini sama gue "Pah aku mau ke rumah Mumut ya. Assalamualaikum". "Han.. Han.. anak kita mualaf kamu tau nggak?"

Kalimat di atas menyatakan proposisi mengenaiseseroang yang mengucapkan salam. Keterkaitan ini dinyatakan dalam dua kalimat yag berkaitan.

\section{c. Kohesi dalam standupPandji Pragiwaksono- "Pendidikan"}

\section{Set up:}

"Ayah.." dia lari ke arah gue sambil bawa kertas. Terus gue bilang "Ini gambar apaan sih?" "Oh ini Chonglin kasih ku gambar" "Ini gambar apa?" "Gambar Angry Bird tapi jelek ya, bego dia"

Kalimat di atas menyatakan proposisi mengenai gambar yang dibawa lalu dijawab dengan proposisi menjelaskan gambar yang dibawa oleh orang tersebut. Keterkaitan ini dinyatakan dalam dua kalimat yag berkaitan.Dalam penelitian ini yang peneliti temukan hanyalah kohesinya saja. Jadi dapat disimpulkan bahwa wacana humor khususnya stand up comedy tidak terdapat koherensi dalam wacana tersebut. Yang muncul hanyalah kohesi itupun dalam sebuah stand up hanya ditemukan jika terdapat percakapan yang diceritakan oleh komika tersebut. 
LINGUA, Vol. 16, No. 1, Maret 2019

p ISSN: 1979 9411; e ISSN: 2442 238X

Http://lingua.pusatbahasa.or.id; Email: presslingua@gmail.com

Center of Language and Cultural Studies, Surakarta, Indonesia

Fitri, Mahyuni \& Sudirman. 2019. Skemata Wacana Humor Stand Up Comedy Indonesia.

Lingua (2019), 16(1): 65 76. DOI: 10.30957/lingua.v16i1.575.

\subsection{Konteks wacana}

Materi pembicaraa para komika pada aksi stand up comedy terikat konteks. konteks memberika pemaknaan terhadap materi teks yang dismapaikan oleh komika. Adapaun deskripsi konteks para komika dalam berkomedi.

\section{Komika I: Raditya Dika}

Pembicara: Raditya Dika
Pendengar: Seluruh penonton yang hadir
Tempat: Salah satu Universitas besar di Indonesia
Waktu: Desember 2016
Situasi: stand up comedy spesial tahunan yang diadakan
Raditya Dika

Komika II: Ernest Prakasa

Pembicara: Ernest Prakasa

Pendengar: Penonton yang hadir di acara tersebut

Tempat: Balai Sarbini Concert Hall

Waktu: 6 Juni 2015

Situasi: Standup spesial keempat dan terbesar Ernest

Prakasa

\section{Komika III: Pandji Pragiwaksono}

Pembicara: Pandji Pragiwaksono

Pendengar: Seluruh penonton yang hadir dalam acara tersebut

Tempat: Teater Jakarta Taman Ismail Marzuki

Waktu: 21 Desember dan 30 April 2017

Situasi: Stand up comedy tahunan yang diadakan Pandji Pragiwaksono dengan tema Mesakke Bangsaku 2013 dan Juru Bicara 2017.

\section{SIMPULAN}

Skemata yang terdapat dalam stand up comedy terlihat dari set up yang dibawakan. Kohesi dan koherensi muncul pada bagian set up, lebih banyak kohesi yang muncul dibanding dengan koherensi. Tema/pembahasan berdasarkan latar belakang masing-masing komika mulai dari agam, status, anak, keluarga, pendidikan, sosial media, dll.Komika-komika di Indonesia seperti Raditya dika, Pandji Pragiwaksono, dan Ernest Prakasamemiliki tema yang berbeda satu sama lain misalnya Raditya dika lebih sering mengusung tema tentang pacaran, jomblo, media sosial dan pengalamannya. Pandji lebih sering mengusung tema tentang sosial dan Ernest mengusung tema tentang pengalamannya jalan-jalan keluar negeri, keluarga dan anaknya.

\section{DAFTAR PUSTAKA}

Badara, Aris. 2012. Analsis Wacana: Teori, Metode, dan penerapannya pada Wacana Media. Jakarta: Kencana. 
LINGUA, Vol. 16, No. 1, Maret 2019

p ISSN: 1979 9411; e ISSN: 2442 238X

Http://lingua.pusatbahasa.or.id; Email: presslingua@gmail.com

Center of Language and Cultural Studies, Surakarta, Indonesia

Fitri, Mahyuni \& Sudirman. 2019. Skemata Wacana Humor Stand Up Comedy Indonesia.

Lingua (2019), 16(1): 65 76. DOI: 10.30957/lingua.v16i1.575.

Mahsun. 2017. Edisi Ketiga Metode Penelitian Bahasa: Tahapan, Strategi, Metode, dan Tekniknya. Depok: Rajawali Pers.

Schiffrin, Deborah. 2007. Ancangan Kajian Wacana. Yogyakarta: Pustaka Pelajar.

Black, Elizabeth. 2016. Stilistika Pragmatis. Yogykarta: Pustaka Pelajar.

Yule, George. 2014. Pragmatik. Yogyakarta: Pustaka Pelajar.

Alwi, Hasan dkk. 2010. Tata Bahasa Baku Bahasa Indonesia Edisi Ketiga. Jakarta:

Balai Pustaka

Wikipedia www.wikipedia.com,diakses pada tanggal 4 Oktober 2018

Pandji Pragiwaksono http://www.youtube.com/user/pandjimusic, diakses pada tanggal 10 September 2018

Raditya Dika http://www.youtube.com/user/radityadika, diakses pada tanggal 16 April 2018

Ernest Prakarsa http://www.youtube.com/user/ernestprakasa, diakses pada tangga 22

$\underline{\text { September } 2018}$ 
LINGUA, Vol. 16, No. 1, Maret 2019

p ISSN: 1979 9411; e ISSN: 2442 238X

Http://lingua.pusatbahasa.or.id; Email: presslingua@gmail.com

Center of Language and Cultural Studies, Surakarta, Indonesia

Fitri, Mahyuni \& Sudirman. 2019. Skemata Wacana Humor Stand Up Comedy Indonesia.

Lingua (2019), 16(1): 65 76. DOI: 10.30957/lingua.v16i1.575. 